УДК 005.73:[159.9:338.46]

DOI https://doi.org/10.26661/2310-4368/2021-1-14

\title{
ТЕОРЕТИЧНИЙ АНАЛІЗ ПРОБЛЕМИ: ОРГАНІЗАЦИЙНА КУЛЬТУРА ЯК ЧИННИК ЗАБЕЗПЕЧЕННЯ ПСИХОЛОГІЧНОГО ЗДОРОВ'Я ПРАЦІВНИКІВ У СФЕРІ ПОСЛУГ
}

\author{
Прошукало І. Л. \\ організаційний психолог, \\ аспірант кафедри психології управління \\ Університет менеджменту освіти \\ вул. Січових Стрільиів, 52-А, Київ, Украӥна \\ orcid.org/0000-0002-9878-7010 \\ igor.pro1983@gmail.com
}

Ключові слова: організачійна культура, соціальна система, організаційні иінності, психологічне здоров'я, організаиійні комунікаиії, сервіс.
У статті аналізується феномен організаційної культури як чинника забезпечення психологічного здоров'я працівників компаній у сфері послуг персоналу (сервісних організацій). Розкривається поняття «організаційна культура» та узагальнюються підходи до виділення типів організаційної культури. Проводиться аналіз специфіки організаційної культури компаній у сфері послуг. Виділені основні типи організаційної культури, які характерні для сфери послуг: клієнтоорієнтований тип організаційної культури, культура збуту та проміжний тип організаційної культури.

Проведений теоретичний аналіз наукової літератури із проблеми психологічного здоров'я особистості дав можливість сформувати розуміння психологічного здоров'я як складної особистісної організації з високим рівнем благополуччя, розуміння себе та інших, наявність уявлень про мету і сенс свого життя, здатність до регулювання свої емоційних станів, вміння 3 повагою ставитися до інших людей і до себе, усвідомлення відповідальності за свою долю і власний розвиток.

На основі теоретичного аналізу наукової літератури 3 проблеми психологічного здоров'я людини та аналізу специфіки діяльності компаній у сфері послуг виділені показники психологічного здоров'я працівників сервісних організацій: орієнтація на досягнення поставлених цілей, емоційна лабільність (врівноваженість), просоціальна оріснтація, фізичне благополуччя, гуманістична позиція, творче самовираження, сімейне благополуччя, духовний розвиток, інтелектуальне вдосконалення, сприйняття себе як неповторної особистості (бажання бути собою). Саме психологічний, інтелектуальний та фізичний компоненти психологічного здоров'я, їх єдність у процесі професійної діяльності працівників сервісних організацій і $є$ однією 3 умов повноцінного особистісного розвитку співробітників.

Розкривається роль і вплив організаційної культури на психологічне здоров'я працівників сервісних організацій через організаційні системи компаніі: систему організаційних цінностей, організаційних комунікацій, соціальну систему. Обгрунтовується, що тип організаційної культури безпосередньо впливає на психологічне здоров'я працівників сервісних організацій і може бути джерелом психологічної напруги серед співробітників компанії у процесі їх професійної діяльності. 


\title{
THEORETICAL ANALISIS OF PROBLEMS: ORGANIZATIONAL CULTURE AS A FACTOR IN ENSURING THE PSYCHOLOGICAL HEALTH OF EMPLOYEES THE SERVICE ORGANIZATIONS
}

\author{
Proshukalo I. L. \\ Organizational Psychologist, \\ Postgraduate Student at the Management Psychology Department \\ University of Educational Management \\ Sichovykh Striltsiv str., 52-A, Kyiv, Ukraine \\ orcid.org/0000-0002-9878-7010 \\ igor.pro1983@gmail.com
}

Key words: organizational culture, social system, organizational values, psychological health, organizational communications, service.

\begin{abstract}
The article analyzes the phenomenon of organizational culture as a factor in ensuring the employee's psychological health of the companies in the field of services (service organizations). The concept of "organizational culture" is revealed and approaches to the selection of types of organizational culture are generalized. The specifics of the organizational culture of the companies in the field of services is analyzed. The main types of organizational culture that are characteristic of the service sector are identified as the customer-oriented type of organizational culture, sales culture, and intermediate type of organizational culture.

Theoretical analysis of the scientific literature on the problem of the individual psychological health made it possible to form an understanding of psychological health as the complex personal organization with a high level of well-being, understanding of themselves and others, ideas about the purpose and meaning of life, ability to regulate their emotional states, the ability to treat other people and yourself with respect, awareness of responsibility for their destiny and their development.

Based on the theoretical analysis of the scientific literature on the problem of human psychological health and analysis of the specifics of the companies in the field of services has been identified the indicators of employees psychological health in the field of services: focus on achieving goals, emotional lability (balance), prosocial orientation, physical well-being, humanistic position, creative self-expression, family well-being, spiritual development, intellectual improvement, perception of oneself as a unique person (desire to be oneself). The psychological, intellectual, and physical components of psychological health, their unity in the process of the professional activity of the service organizations employees is one of the conditions for full personal development of employees.

The role and influence of organizational culture on the psychological health of the service organizations employees are revealed through the organizational systems of the company - the system of organizational values, organizational communications, social system. It is substantiated that the type of organizational culture directly affects the psychological health of the service organizations employees and can be a source of psychological stress among employees in the course of their professional activities.
\end{abstract}

Постановка проблеми в загальному вигляді. Сучасне бачення працівника у сфері послуг (сервісній сфері) - це гармонійна особистість, яка впевнена у своїх силах, позитивно ставиться до себе і оточуючих, вміє орієнтуватися в потоках інформації, приймати рішення i нести за нього відповідальність, ефективно взаємодіяти 3 іншими людьми (колегами, клі- єнтами), здатна брати на себе відповідальність і готова до постійного професійного та особистісного саморозвитку. Важливу роль у цьому процесі відіграє організаційна культура, яка виступає певним атрибутом, що активно впливає на всіх членів організації через вимоги до працівників у процесі їх професійної діяльності. 
Актуальність теми також підтверджується тим фактом, що організаційна культура як у сфері послуг, так і в інших сферах бізнесу в Україні часто продовжує сприйматися здебільшого управлінською ланкою тільки крізь призму вітань зі святами та корпоративними заходами і в такому вигляді продовжує реалізовуватися на практиці.

Відсутнє бачення організаційної культури як соціально значущого інструмента управління персоналом загалом і як одного з чинників психологічного здоров'я працівників зокрема призводить до втрачених можливостей соціального розвитку персоналу організації i не дозволяє своєчасно впливати на стратегію розвитку організації, щоб залишатися конкурентноспроможною на ринку в сучасних складних умовах.

Нині професійна діяльність працівників сфери послуг насичена безліччю організаційних і соціально-психологічних стресів, а, враховуючи, що значну частину свого життя людина проводить на роботі, то умови праці, взаємини 3 колегами, перспективи подальшого кар'єрного зростання визначають не тільки якість виконання нею своїх професійних обов'язків, а і пї фізичний і психологічний стан. Кожен елемент організаційної культури має свій вплив на те, як швидко особистість адаптується до нового організаційного середовища і почне своє професійне становлення та зростання. Саме тому важливо формувати правильне розуміння організаційної культури та i впливу на розвиток як окремої особистості, так i компанії загалом.

Аналіз останніх досліджень і публікацій. Аналіз наукової літератури $з$ проблеми ролі організаційної культури як чинника забезпечення психологічного здоров'я працівників сервісних організацій дає змогу виділити два напрями досліджень. До периого напряму входять дослідження, в яких розглядаються теоретико-методологічні основи організачійної культури, які були предметом спеціальних досліджень західних дослідників (Р. Дафт, Т. Діл, К. Камерон, Р. Куїн, Р. Льюїс, I. Оучі, Е. Шейн) і вчених ближнього зарубіжжя (О. Віханський, І. Ладанов, А. Наумов, С. В. Снєтков, О. Стеклова, В. Томілов, К. Ушаков, Р. Хувейк).

Протягом останніх років українські дослідники також приділяють достатньо уваги проблемі формування та розвитку організаційної культури у різних сферах: промисловості (Г. Захарчин, Т. Калініченко, Л. Карамушка, І. Сняданко, О. Харчишина), бізнесі (А. Овчаренко, М. Станіславська, О. Францев та ін.), вищій школі (А. Апішева, Н. Завацька, О. Іщук, О. Мітічкіна, Л. Спіцина, О. Бондарчук), державній службі (Н. Баранюк, О. Король, Л. Малімон, К. Охотницька).

До другого напряму належать дослідження, присвячені проблемі психологічного здоров'я людини в окремих аспектах. Зокрема, ця проблематика була започаткована ще у працях зарубіжних дослідників А. Маслоу, Г. Олпорта, К. Роджерса, В. Франкла, Е. Фрома і продовжує бути актуальною темою дослідження як сучасних українських науковців, так і дослідників ближнього зарубіжжя: О.В. Алексєєв (настрій і здоров'я); М.Й. Боришевський (психологія самоактивності та суб'єктного розвитку особистості як саморегульованої соціально-психологічної системи); Б. С. Братусь (аномалії особистості); І. В. Дубровіна (психологічне здоров'я учасників освітнього процесу); Л.Д. Дьоміна, І.О. Ральникова (психічне здоров’я та захисні механізми особистості); Г.В. Ложкін, М.І. Мушкевич, О.В. Наскова, І.В. Толкунова (психологія здоров'я людини); Г.С. Нікіфоров (психологія здоров'я); В.М. Панкратов (саморегуляція психічного здоров'я); Д.Д. Федотов (збереження психічного здоров'я); О.В. Хухлаєва (особливості психічного здоров'я студентів); О.Я. Чебикін (проблема емоційної стійкості); М. Тимофієва, Г. Попова (розвиток психологічно здорової особистості з урахуванням потреб віку)та інші.

Аналіз наукової літератури вказує на те, що проблема дослідження організаційної культури хоча і має певні напрацювання щодо забезпечення психологічного здоров'я персоналу в різних сферах професійної діяльності, проте вона недостатньо розроблена в контексті сфери послуг.

Мета статті - проаналізувати роль організаційної культури як одного $з$ важливих чинників забезпечення психологічного здоров'я працівників компаній у сфері послуг.

Виклад основного матеріалу. Нині значно зросла і продовжує зростати роль організаційної культури в розвитку сучасних організацій, особливо в період теперішніх соціальних та економічних змін. Організаційна культура стає тим сучасним інструментарієм менеджменту, який допомагає в управлінні не тільки матеріальними цінностями організації, а й духовними.

Теоретичний аналіз наукової літератури дає нам різні дефініції поняття «організаційна культура». Зокрема, Майкл Армстронг стверджував, що організаційна культура - це сукупність переконань, відносин, норм поведінки і цінностей, спільних для всіх працівників такої організації [1]. Дослідник організаційної культури Едгар Шейн визаначав організаційну культуру як сукупність основних переконань, сформованих самостійно, засвоєних або розроблених певною групою [2]. М. Мескон трактує культуру як клімат в організації; вона відображає звичаї, притаманні організації [3]. А. Елдрідж та А. Кромбі розуміють під культурою організації унікальну сукупність норм, цінностей, переконань, зразків поведінки, які визначають спосіб об'єднання груп і окремих осо- 
бистостей в організацію для досягнення поставлених перед нею цілей визначають [4]. Це визначення організаційної культури доповнює У. Оучі. На його думку, організаційна культура - символи, церемонії та міфи, які повідомляють членам організації важливі уявлення про цінності і переконання [5].

Дослідженню ролі організаційної культури приділили значну увагу і дослідники ближнього зарубіжжя. На думку В. Каткова, організаційна культура представляє собою систему формальних і неформальних правил і норм діяльності, звичаїв і традицій, індивідуальних і групових інтересів, особливостей поведінки працівників у такій організації, що вирізняються стилем поведінки, показниками задоволеності роботою, рівнем взаємного співробітництва, ступенем ідентифікації працівників з організацією та цілями іiї розвитку [6].

Українські дослідники О. Харчишина і О. Креденцер визначають організаційну культуру як набір найбільш важливих припущень, прийнятих членами організації, що одержують вираження в заявлених організацією цінностях, які задають людям орієнтири їх поведінки і дій. Ці ціннісні орієнтації передаються індивідам через «символічні» засоби духовного і матеріального внутрішньо-організаційного оточення [7; 8].

Українська дослідниця Л. Карамушка визначає організаційну культуру як «набір переконань, цінностей і засвоєних способів вирішення реальних проблем, що сформувався за час життя організації і має тенденцію вияву в різних матеріальних формах і в поведінці членів організації» [9, с. 16-17].

О. Моргулець розглядає «власне культуру сервісного підприємства як певні принципи та етичні норми обслуговування клієнтів, а тому культура обслуговування - це і $є$ організаційна культура сервісного підприємства, яка спрямована на обслуговування клієнтів на основі вироблення певних правил, процедур, практичних навичок вмінь» [10, с. 353$]$.

Попри очевидну розмаїтість визначень і тлумачень організаційної культури, все ж таки більшість авторів доходять спільного розуміння поняття «організаційної культури» як своєрідного сплаву філософії та ідеології організації, цінностей, норм і переконань, властивих іiі членам, відповідно до якого вони здійснюють свої дії.

Нині існує безліч різних підходів до виділення типів організаційної культури, але загалом їх можна розділити на дві основні групи: прості за характером формування, за ступенем сформованості, за характером впливу на ефективність діяльності організації, за охопленням, за характером існування та більш складні, які засновані на змістовних характеристиках та являють собою сукупність певних ознак - це національні осо- бливості (модель Ф. Клукхольма-Ф. Стродберга, типології Ф. Тромпенаарса і Ч. Хемпден-Тернера, Г. Хофстеде); галузеві особливості (типології Т. Діла і А. Кеннеді, М. Бурке, Д. Зоненфельда); типології, засновані на теоріях психології особистості (типологія М. Марка і К. Пірсона, заснована на 12 базових архетипах людської психіки i типологія Ф.Р. Манфреда, Ке де Бреши і Д. Міллера, заснована на психопатологічних критеріях, властивих особистостям); особливості гендерних взаємин (типологія С. Медока і Д. Паркина); домінуючі цінності (типологія С. Ханді); конкуруючі цінності (К. Камерона і Р. Куїнна). Здебільшого описані вище типи організаційної культури в чистому вигляді у компаніях не зустрічаються, а поєднують у тій чи іншій мірі всі типи організаційних культур, де один із них все таки може переважати. У деяких організаціях різні підрозділи i департаменти навіть можуть демонструвати різні типи культури.

Якщо брати до уваги, що базовим рівнем будьякої організаційної культури є ії корпоративна ідеологія та філософія, яка впливає на інтереси усіх суб'єктів організаційного процесу, то саме специфіка тієї чи іншої сфери і сприяє якісним відмінностям організаційних культур, а також цілям, які перед собою ставить та чи інша організація.

Сфера послуг являє собою особливий вид соціальної діяльності, спрямований як на забезпечення функціонування виробничої та соціальної сфери загалом, так і безпосередньо на потреби домашнього господарства, сім'ї та особистості. «Споживач, а не компанія знаходиться в центрі. ... Компанії обертаються навколо клієнта, а не навпаки. Дедалі більшого прийняття цієї концепції, в центрі якої споживач, має і буде мати далекосяжні наслідки, виробляючи справжню революцію в економічному мисленні», - стверджує Р. Кейтс [11, с. 52].

На цьому принципі побудована концепція CRM (Customer Relationship Managment - управління взаємовідносинами з клієнтами), де ядром $€$ клієнтоорієнтований підхід, коли всі засоби і способи комунікації з клієнтом повинні працювати так, щоб мати можливість задовольняти потреби та очікування останнього. Тому клієнтоорієнтований тип організаційної культури компаній у сфері послуг - система організаційних цінностей, ідеологія та філософія, які допомагають організації максимально успішно задовольняти потреби клієнтів та бути конкуретноспроможними на ринку, надаючи якісний сервіс (обслуговування).

На противагу клієнтоорієнтованій організаційній культурі сервісної організації можна виокремити організаційну культуру збуту, коли головною цінністю $є$ отримання прибутку за будьякої ситуації, а клієнт, реальний чи потенційний, 
розглядається як засіб для отримання цього прибутку з найменшими вкладеннями та витратами. При такій організаційній культурі у працівників сервісних організацій відсутне розуміння такого поняття як «клієнтоорієнтованість», розвиток якого до того ж може блокуватися традиціями та нормами самої компанії.

Існує у сфері послуг і проміжний тип організаційної культури, коли турбота про клієнта пропорційна одержуваному від нього прибутку. При такому підході формується вибіркове ставлення до клієнтів залежно від отримання можливого прибутку. Та все ж організаційна культура компаній у сфері послуг (сервісних організаціях) будується на корпоративній ідеології та філософiï, де цінності людських емоцій є важливішими, ніж фізичні характеристики самої послуги. Адже саме ці нематеріальні, «емоційні» цінності надають послугам статус сервісної послуги, а тип відносин, які складаються між продавцем і споживачем - сервісні відносини, також $\epsilon$ специфічною цінністю. У підсумку купуються саме цінності - філософська концепція послуги, яка і виділяе сервісну організацію серед конкурентів на ринку. Чим більше цінностей додається до послуги, тим сама послуга вже стає лише константою, і тоді можемо говорити про високий рівень сервісу.

У процесі створення послуги важливо розуміти на скільки активно залучений клієнт у цей процес. Тоді можна стверджувати про якість сервісу цієї послуги, суть якого полягає в орієнтації на максимальне задоволення потреб своїх клієнтів - клієнтоорієнтованість. Саме вона стає основоположною цінністю клієнтоорієнтованої організаційної культури і розглядається керівництвом i співробітниками як регулятор особистісного та організаційного успіху, розвитку. Це формує розуміння спільних цінностей.

В умовах активного розвитку сфери послуг ще більшого значення набуває високий рівень професіоналізму і компетентності співробітників сервісних організацій, які працюють із клієнтами, причому поняття професіоналізму у сервісній діяльності передбачає не тільки відповідні знання і вміння працівників, а й їхні цінності та установки, орієнтовані на те, що клієнт - персоніфікований об' єкт турботи.

Нині організаційна культура сучасних сервісних організацій орієнтована на високий рівень обслуговування клієнтів і вимагає від співробітників великих професійних затрат, які часто перевищують їх особистісні ресурси. У зв'язку 3 цим емоційна стійкість і високий рівень адаптивності до різного роду психогенних впливів розглядаються як професійно значущі якості особистості працівника сервісної організації, а тому психологічне здоров'я $є$ необхідною умовою пов- ноцінного функціонування і розвитку працівників сфери послуг.

Наразі проблемі психологічного здоров'я людини приділяється досить велика увага. Проте початок ії вивчення був покладений ще у працях А. Маслоу, Г. Олпорта, К. Роджерса, В. Франкла, Е. Фрома, Б.С. Братуся, I.В. Дубровіної. Кожен із цих дослідників вкладав різний зміст у поняття «психологічне здоров'я». А. Маслоу стверджував, що психологічно здоровою $є$ самоактуалізована особистість. Тут для змістовного розкриття категорії «психологічне здоров'я» можна використовувати визначення «людяність», дане А. Маслоу $[12$, c. 121$]$.

«Психічне здоров'я традиційно інтерпретується як власна життєздатність індивіда, як життєва сила, забезпечена повноцінним розвитком $\mathrm{i}$ функціонуванням психічного апарату, як вміння виживати, пристосовуватися і рости в умовах, що змінюються, не завжди сприятливих для більшості умовах, i $€$ передумовою здоров'я психологічного. Психологічне здоров'я характеризує індивіда як суб'єкта життєдіяльності, розпорядника своїх власних сил і здібностей» [12, с. 122]. Доповнення цієї думки знаходимо у напрацюваннях А. Шувалова [13, с. 26]. Відповідно, психологічне здоров'я - це стан, що характеризує процес i результат нормального розвитку суб'єктивної реальності в межах індивідуального життя; максимумом психологічного здоров'я $\epsilon$ інтеграл (тобто єдність, повнота і цілісність) життєздатності і людського індивіда [13, с. 27].

Сучасні дослідники проблеми психологічного здоров'я, зокрема I.В. Дубровіна, розглядають поняття «психологічне здоров'я» як динамічну сукупність психічних властивостей особистості, що забезпечують гармонію між потребами індивіда й суспільства і виступають передумовою орієнтації індивіда на виконання своє життєвої задачі. Для визначення норми психологічного здоров'я важлива наявність певних особистісних характеристик, які допомагають людині не лише успішно адаптуватися, а й продуктивно розвиватися на благо самій собі і суспільству через саморозуміння, самоприйняття та самовдосконалення [14].

Г.І. Малейчук зазначає, що психологічне здоров'я $\epsilon$ вищим рівнем вияву здоров'я психічного. На думку автора, воно визначається ціннісно-смисловим змістом розвитку особистості [15].

В.С. Хомік пропонує розглядати психологічне здоров'я 3 точки зору реверсивної теорії особистості М. Аптера, який пропонує концепцію мотиваційного розмаїття: психологічне здоров'я залежить від повноти емоційних і поведінкових виявів. Воно виявляється у великому спектрі психологічних станів, широкій гамі емоційних 
регістрів і переживанні мотиваційного розмаїття. Умовами здорового соціального розвитку особистості є зміни, непослідовність і нестабільність [16].

M. Jahoda до критеріїв психологічного здоров'я відносить позитивну установку стосовно своєї особистості, духовне зростання і самореалізацію, інтегровану особистість, автономію, самодостатність, адекватність сприйняття реальності і компетентність у подоланні вимог оточуючого світу [17]. K. Menninger називає такі ознаки як відчуття щастя, задоволеність, врівноважений темперамент, інтелектуальність і взірцева соціальна поведінка [18].

Проведений теоретичний аналіз наукової літератури з проблеми психологічного здоров'я особистості підкріплює наше розуміння психологічного здоров'я як складної особистісної організації з високим рівнем благополуччя, розуміння себе та інших, наявність уявлень про мету і сенс свого життя, здатність до регулювання свої емоційних станів, вміння $з$ повагою ставитися до інших людей і до себе, усвідомлення відповідальності за свою долю і свій розвиток.

Психологічне здоров'я працівників сервісних організацій пов'язане 3 їх професійною діяльністю, оскільки в центрі безпосередньо стоїть особистість працівника. Спираючись на аналіз наукової літератури 3 проблеми психологічного здоров'я особистості та специфіку діяльності сервісних організацій, ми виділили такі показники психологічного здоров'я працівників у сфері послуг: орієнтація на досягнення поставлених иілей; емоційна лабільність (врівноваженість); просоиіальна орієнтація - прагнення до розвитку міжособистісних стосунків внутрішньо групової взаємодії, спілкування та спільної діяльності; фізичне благополуччя - здатність працівником розвивати фізичний складник свого здоров'я, усвідомлювати свою тілесність як властивість власної особистості; гуманістична позиція - світоглядні орієнтації працівників, що характеризується системою уявлень, переконань, норм і принципів соціально схвальної поведінки, головними категоріями яких є відповідальність, турбота, повага до себе та інших людей; творче самовираження - здатність працівників до творчої активності, творчості; сімейне благополуччя - благополучні сімейні відносини поряд із професійними виступають важливою сферою реалізації потенціалу особистості; духовний розвиток - здатність працівників розвивати свою духовну природу; інтелектуальне вдосконалення - здатність працівників розвивати свій інтелект та вміти користуватися ним; сприйняття себе як неповторної особистості (бажання бути собою).
Саме психологічний, інтелектуальний та фізичний компоненти психологічного здоров'я, їх єдність у процесі професійної діяльності працівників сервісних організацій і $є$ однією з умов повноцінного особистісного розвитку співробітників.

Серед чинників, що впливають на забезпечення психологічного здоров'я персоналу у сфері послуг важливу роль відіграє організаційна культура, яка реалізується через такі системи організації: система організаційних цінностей, система організаційних комунікацій, соціальної систему. Це можна представити у вигляді теоретичної моделі (рис. 1).

Система організаиійних иінностей, що відображає ідеологію компанії та виконує роль ціннісного ядра, яке об'єднує внутрішнє і зовнішнє середовища, інтегрує інтереси всіх працівників компанії, формує певні норми поведінки та почуття причетності до професійної спільноти, покликане сприяти виконанню місії і досягненню стратегічних пріоритетів компанії.

Організаційні цінності виступають основними елементами організаційної культури. Вони виконують регуляційну функцію, показуючи, які соціальні дії є прийнятними в цій організації, а від яких варто відмовитися. Колективні організаційні цінності орієнтують співробітників на певні зразки поведінки, які можуть бути як позитивними, підтримують досягнення організаційних цілей, так і негативними, негативно впливають на організаційну продуктивність.

3 організаційних цінностей компанії виростають організаційні норми, які виступають організаційними правилами поведінки і безпосередньо вказують працівникам, які дії є дозволеними $\mathrm{i}$ бажаними, а які - неприпустимими.

Ефективне управління процесом забезпечення психологічного здоров'я персоналу в компанії формується на загальноприйнятих організаційних цінностях, які сприяють саморозвитку працівників на всіх рівнях організації не тільки в межах своєї професійної компетенції, але й на рівні особистісного саморозвитку у позаробочий час.

Система організаиійних комунікаиії охоплює усі форми комунікаційних зв'язків всередині компанії: від спілкування співробітників між собою, управлінською ланкою та працівниками, організації зворотного зв'язку, інтенсивності комунікацій до спілкування з клієнтами компанії.

Психологічна наука розглядає поняття «комунікація» як психічний процес, що відповідає за вербальний і невербальний спосіб прийому та передачі інформації і передбачає міжособистісне спілкування. Проте, на наш погляд, варто говорити все ж таки про комунікацію як більш об'ємний процес і як одну з найважливіших психофізіологічних потреб людини, яка як і інші потреби 


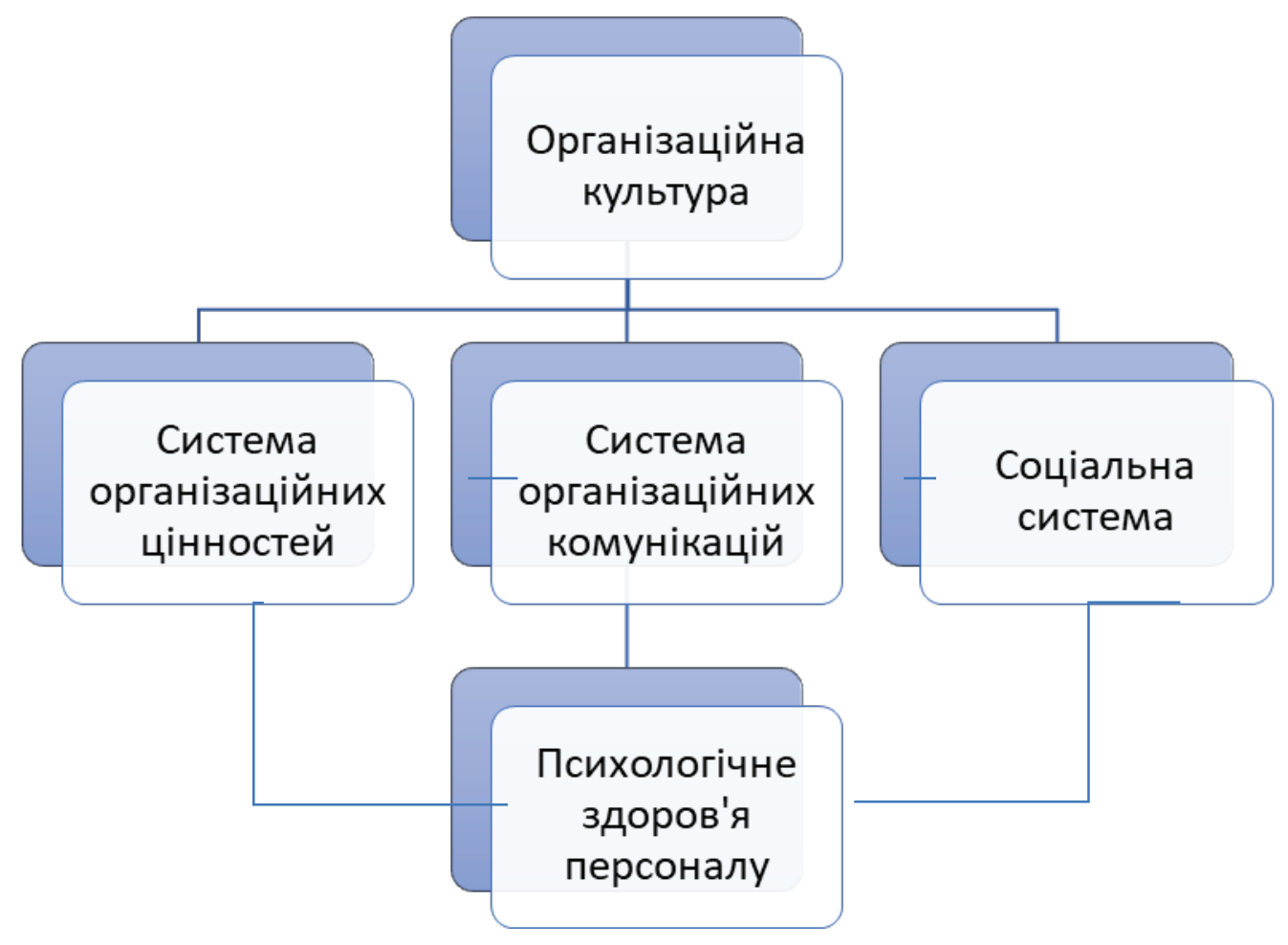

Рис. 1. Теоретична модель впливу організаційної культури на забезпечення психологічного здоров'я персоналу

може бути реалізована через взаємодію з навколишнім середовищем і світом загалом.

Одним із джерел забезпечення психологічного здоров’я працівників у компанії виступають організаційно-комунікативні умови організаційного середовища, тобто організація міжособистісних взаємодій суб'єктів таким чином, щоб дати можливість працівникам проявитися у повній мірі як особистості, в тому числі і через комунікацію.

Очевидно, що працівник, перебуваючи на роботі цілий день і виконуючи свої безпосередні функціональні обов'язки, включається у комунікативний процес всередині компанії, встановлює міжособистісні контакти та контролюється певним стилем керівництва. Таким чином, сприятлива робоча атмосфера допомагає ефективному виконанню професійних завдань, приносить задоволення від самого процесу роботи. Нервово-напружена обстановка мало сприяє продуктивній діяльності працівника. Несприятливі враження від робочого дня поширюється на позаробочий час працівника і можуть набувати циклічної форми: несприятлива робоча атмосфера тягне за собою непродуктивну діяльність, появу психоемоційного напруження, що нівелює адекватну комунікацію не тільки всередині компанії, але й впливає на комунікацію із клієнтами.

Від того, як побудовані комунікації всередині компанії між управлінською ланкою і співробіт- никами, спілкування між самими співробітниками та клієнтами компанії, де важливою характеристикою $є$ тип організаційної культури сервісної організації: конструктивний і прогресивний, спрямований на збереження і зміцнення психологічного здоров'я працівників, або ж регресивний, спрямований на деструктивні дії щодо психологічного здоров'я співробітників, залежить від управлінської ланки, культури управління та організованого зворотного зв'язку всередині компанії для співробітників.

Соиіальна система знаходить своє вираження в соціальній структурі організації та нормах взаємин працівників, прийнятих в організації. Організаційна культура формує у компанії певний організаційний клімат. Він являє собою соціальні зв'язки всередині організації, які виражаються в емоціях, настроях і переживаннях членів організації, що впливають на їх поведінку в процесі професійної діяльності. Ці зв'язки формуються за допомогою взаємодії організаційних і особистісних цілей, задач, формальної структури, стилю керівництва і поведінки працівників.

Здоровий організаційний клімат у компанії дозволяє співробітникам відчувати себе комфортно в організації, задовольняти свої потреби в спілкуванні і самоактуалізації. Організаційний клімат характеризується загальними організаційними цінностями працівників компанії та ії керів- 
ництва. Відсутність здорового організаційного клімату призводить до втрати мотивації персоналом і зниження продуктивності праці, тому він такий важливий для саморозвитку персоналу на підприємстві, а відтак і психологічного здоров'я.

Організаційна культура як соціальна детермінанта впливає на психологічне здоров'я працівників також за допомогою рольової моделі: показує приклад поведінки, який передбачається закріпити і розвинути у співробітників компанії. Працівники засвоюють нові патерни поведінки за допомогою наслідування керівника та більш авторитетних колег, що в подальшому впливає і на комунікацію з клієнтами компанії. На формування організаційної культури і патернів поведінки, які сприяють психологічному здоров'ю працівників сервісних організацій, насамперед впливає поведінка керівника.

У цьому випадку важливим для психологічного здоров'я працівників сервісних організацій $€$ те, наскільки співробітник сприймає організаційне оточення як середовище, яке для нього $\epsilon$ безпечним і зрозумілим, узгодженим із власною системою цінностей та 3 оцінкою своїх ресурсів. Наскільки він володіє внутрішніми силами для адаптації до тих організаційних умов, які можуть викликати певну психологічну напругу, що створює передумови для виникнення стресових станів.

3 цієї точки зору джерелом забезпечення психологічного здоров'я працівників сервісних організацій варто шукати не тільки в організації відповідного організаційного середовища, але й сприяти розвитку організаційної культури компанії як через вплив на працівників підприємства за допомогою цінностей і установок, традицій і ритуалів, так і через організаційні норми і зразки поведінки (рольових моделей) і таким чином розкривати власні ресурси працівників, сприяти процесам особистісного розвитку та самореалізації.

Висновки. Психологічне здоров'я особистості - це безперервний рух до самовдосконалення, а головна роль у його збереженні та розвитку належить самій людині. Проте, проводячи більшість свого часу на роботі у вирішенні професійних завдань, важливу роль у збереженні та розвитку психологічного здоров'я відіграє організація.
Сфера послуг як вид професійної діяльності зосереджена на взаємодії «людина - людина», а тому потребує особливої уваги до психологічного здоров'я своїх працівників, коли особистість працівника, його поведінка, система цінностей, внутрішня гармонія із собою відіграють важливу роль у відносинах і спілкуванні з клієнтами. Особливу роль у цьому процесі відіграє організаційна культура, яка реалізується в компанії через систему організаційних цінностей, що відображає ідеологію компанії та виконує роль ціннісного ядра, навколо якого об'єднуються працівники для досягнення організаційних та особистих цілей; система організаційних комунікацій, яка охоплює всі форми комунікацій всередині компанії та сприяє встановленню відповідних соціальних зв'язків та обміну інформацією між управлінською ланкою та працівниками, між самими співробітниками; соціальна система, яка забезпечує норми взаємин, прийняті в організації, що загалом визначає характер і ступінь сприятливості для співробітників соціально-психологічної атмосфери у колективі і компанії загалом. Таким чином, забезпечуючи якісний розвиток організаційної культури на рівні різних систем, компанія має можливість сприяти забезпеченню психологічного здоров'я своїх працівників.

Варто зазначити, що при формуванні та розвитку в компанії організаційної культури слід враховувати тип організаційної культури і вибудовувати соціальні норми, установки і цінності, які мотивують персонал до розвитку професійної та особистісної компетенції. Саме конструктивна організаційна культура 3 високим рівнем культури управління буде спрямовувати і мотивувати працівників на продуктивну, якісну та ініціативну роботу, розкриваючи професійний і творчий потенціал працівників сервісних організацій, сприяти особистісному розвитку, а тому і психологічному здоров'ю співробітників.

Психологічне забезпечення працівників сервісних організацій залежить не тільки від організаційної культури, але й від комплексу інших факторів, що визначають бажання співробітників компаній у сфері послуг самостійно підвищувати свій рівень професійного і особистісного розвитку. У цьому автор і вбачає перспективи подальших досліджень.

\section{ЛІТЕРАТУРА}

1. Корпоративна культура : навч. посіб. / за заг. ред. Г.Л. Хаєта. Київ : Центр навчальної літератури, 2003. $150 \mathrm{c}$.

2. Шейн Э.Х. Организационная культура и лидерство / Пер. с англ. под ред. В.А. Спивака. Санкт-Петербург : Питер, 2002. 336 с.

3. Мескон М.Х., Альберт М., Хедоури Ф. Основы менеджмента = Management / Пер. с англ. третьего изд. М. : Дело, 1998. 800 с.

4. Eldridge J., Crombie A. A sociology of organization. London : Allen\&Unwin, 1974. 
5. Ouchi W. Theory "Z”: How American business can meet the Japanese challenge. Reading, MA: AddisonWesley, 1981.

6. Катков В. Формирование организационной культуры на промышленном предприятии. Управление персоналом. 2000. № 2. С. 15.

7. Харчишина О.В. Формування організаційної культури в системі менеджменту підприємств харчової промисловості : монографія. Житомир : Вид-во Житомирського державного університету ім. І. Франка, 2011. 289 с.

8. Креденцер О.В. Теоретичний аналіз типологій організаційної культури. Актуальні проблеми психології: Організачійна психологія. Економічна психологія. Сочіальна психологія : зб. наук. прачь Інституту психології імені Г.С. Костюка НАПН України. Київ - Алчевськ. 2013. Т. І. Вип. 37. C. $17-21$.

9. Карамушка Л.М. «Прогресивні» та «консервативні» типи організаційної культури: порівняльний аналіз організаційної культури загальноосвітніх навчальних закладів традиційного та інноваційного типів. Актуальні проблеми психології: Організаційна психологія. Економічна психологія. Соціальна психологія : зб. наук. праџь Інституту психології імені Г.С. Костюка НАПН Украӥни. Київ Алчевськ. 2014. Т. 1. Вип. 40. С. 15-20.

10. Моргулець О.Б. Менеджмент у сфері послуг : навч. посіб. / за ред. О.Б. Моргулець. Київ : Центр учбової літератури, 2012. 383 с.

11. Архангельский Г.А. От удовлетворения потребителя к реализации ценностей. Рекламные идеи. 2003. № 1(42). С. 52-53.

12. Маслоу А. Дальние пределы человеческой психики. Санкт-Петербург : Евразия, 1997. 322 с.

13. Шувалов А.В. Психологическое здоровье человека. Вестник. 2009. Вып. 4 (15). С. 87-101.

14. Руководство практического психолога. Психическое здоровье детей и подростков в контексте психологической службы / А.Д. Андреева и др.; / под ред. И.В. Дубровиной. Москва : Изд. Центр «Академия», 1998. $166 \mathrm{c.}$

15. Малейчук Г.И. Психическое и психологическое здоровье: сравнительный анализ понятий. Психология и школа. 2004. № 3. С. 24-34.

16. Хомик В.С. Психологическое здоровье личности. Структурно-феноменологический подход. Практична психологія і соиіальна робота. 1999. № 5. С. 5-9.

17. Jahoda M. Current concepts of positive mental health / M. Jahoda. New York, 1958. 465 p.

18. Menninger K. The Human mind / K. Menninger. New York, 1946. 457 p.

\section{REFERENCES}

1. Khaiet H.L. (ed.). (2003) Korporatyvna kuljtura : navch. posib. [Corporate culture : teaching guide]. Kyiv : Tsentr navchalnoi literatury (in Ukrainian).

2. Shejn Je. (2002) Organizatsionnaya kul'tura i liderstvo [Organizational Culture and Leadership]. St. Petersburg : Piter (in Russian).

3. Meskon M.H., Al'bert M., Hedouri F. (1998) Osnovy menedzhmenta = Management [Management basics $=$ Management]. Moscow : Delo (in Russian).

4. Eldridge J., Crombie A. (1974) A sociology of organization. London : Allen\&Unwin.

5. Ouchi W. (1981) Theory "Z": How American business can meet the Japanese challenge. MA : Addison-Wesley.

6. Katkov V. (2000) Formirovanie organizatsionnoy kul'tury na promyshlennom predpriyatii. [Formation of organizational culture in an industrial enterprise ]. Personnel Management, № 2, p. 15.

7. Kharchyshyna O.V. (2011) Formuvannja orghanizacijnoji kuljtury v systemi menedzhmentu pidpryjemstv kharchovoji promyslovosti : monoghrafija [Formation of organizational culture in the management system of food industry enterprises : monograph]. Zhytomyr : Edition of Zhytomyr Ivan Franko State University [in Ukrainian].

8. Kredentser O.V. (2013) Teoretychnyj analiz typologhij orghanizacijnoji kuljtury [Theoretical analysis of the typologies organizational culture]. Actual Problems of Psychology: Organizational psychology. Economic psychology. Social psychology: collection of scientific papers of G.S. Kostiuk Institute of Psychology NAPS Ukraine, tome 1, vol. 37, p. 17-21.

9. Karamushka L.M. (2014) "Proghresyvni" ta "konservatyvni" typy orghanizacijnoji kuljtury: porivnjaljnyj analiz orghanizacijnoji kuljtury zaghaljnoosvitnikh navchaljnykh zakladiv tradycijnogho ta innovacijnogho typiv ["Progressive" and "conservative" types of organizational culture: a comparative analysis of the secondary schools organizational culture with traditional and innovative types]. Actual Problems of Psychology: Organizational psychology. Economic psychology. Social psychology: 
collection of scientific papers of G.S.Kostiuk Institute of Psychology NAPS Ukraine, tome 1, vol. 40, p. $15-20$.

10. Morhulets O.B. (2012) Menedzhment u sferi poslugh : navch. posib. [Management in the field of services : teaching giude]. Kyiv : Centr uchbovoji literatury (in Ukrainian).

11. Arhangel'skij G.A. (2003) Ot udovletvoreniya potrebitelya k realizatsii tsennostey [From consumer satisfaction to value realization]. Advertising ideas, vol. 1(42), p. 52-53.

12. Maslou A. (1997) Dal'nie predely chelovecheskoy psikhiki [The far reaches of the human psyche]. St. Petersburg : Evrazija (in Russian).

13. Shuvalov A.V. (2009) Psikhologicheskoe zdorov'e cheloveka [Human psychological health]. Bulletin, vol. 4 (15), p. 87-101.

14. Andreeva A.D., Dubrovina I.V. (1998) Rukovodstvo prakticheskogo psikhologa: Psikhicheskoe zdorov'e detey i podrostkov v kontekste psikhologicheskoy sluzhby [Practical Psychologist's Guide: Child and Adolescent Mental Health in the Context of Psychological Services]. Moscow : Akademija (in Russian).

15. Malejchuk G.I. (2004) Psikhicheskoe i psikhologicheskoe zdorov'e: sravnitel'nyy analiz ponyatiy [Mental and psychological health: a comparative analysis of concepts]. Psychology and school, № 3, p. $24-34$.

16. Homik V.S. (1999) Psikhologicheskoe zdorov'e lichnosti. Strukturno-fenomenologicheskiy podkhod [Psychological health of a person. Structural-phenomenological approach]. Practical psychology and social work, № 5, p. 5-9.

17. Jahoda M. (1958) Current concepts of positive mental health. New York.

18. Menninger K. (1946) The Human mind. New York. 